\title{
EVALUATION OF LAND USE WITH LAND CAPABILITY CLASSIFICATION USING SATELLITE DATA AND GIS IN BATUR UNESCO GLOBAL GEOPARK
}

\author{
I Putu Wira Utama ${ }^{1 *}$, I Wayan Sandi Adnyana ${ }^{2)}$ \\ ${ }^{1)}$ Bappeda Litbang of Bangli Regency \\ ${ }^{2)}$ Environment Science Postgraduate Program Udayana University \\ *E-mail: wira_ajus@yahoo.com
}

\begin{abstract}
Development in Batur UNESCO Global Geopark has increased significantly in recent years. The land use changes in Bangli regency that the plantation, built-up/residential and tourism support facilities development increased quickly, especially in Kintamani district. To know the suitability of land use in Batur UNESCO Global Geopark area, it is necessary to evaluate land use with land capability classification. Landsat 8 remote sensing data on 27 September 2017 was used to create land use maps. Land use maps obtained through the process of image classification using supervised classification method and verified by ground check, this technique result 10 classes of land use. Land capability class map generated from improvisation overlay methods, reclassification of differentiator classes into the differentiator value of a raster data pixel (differentiator pixel value method). Furthermore, to evaluate of land use suitability was conducted by comparing land use with land capability class. In this process, there is an overlay between the land use maps with land capability class map using geographic information system (GIS). The results of evaluation land use in Batur UNESCO Global Geopark with land capability class overall has suitable area $15,764.78$ ha $(88.49 \%)$, not suitable area $1,767.48$ ha (9.92\%) and not detected/cloud interference 283.67 ha (1.59\%).
\end{abstract}

Keywords: evaluation of land use, land capability, satellite data, GIS, geopark.

\section{INTRODUCTION}

Land as one component of space plays an important role in human activities. The fulfillment of the need for land for the development process and human activities is increasingly becoming one of the causes of the dynamics of use. Limited land if associated with the need to meet human needs and development there will be a conflict of interest, because the land use and development more rapidly while the available land has a fixed area.

Soil mapping of Research Center of Agriculture Ministry, show Kintamani area consists of litosol, arenosol, and andosol soil type (BBSDLP, 2016). The soil is formed from volcanic ash intermediary with volcanic cone physiology, caldera valley, and volcanic volumes (Nampa, 2011). The shape of the area in Kintamani district is ramps, bumpy, choppy, and mountainous. Effective depth of soil thin to thick, color of soil is generally gray to yellow, with sand texture with less than $40 \%$ clay content (RTRW, 2013). The soil chemical properties have a very varied acidity, low organic matter content, basic saturation varies, low adsorption capacity, several of nutrient content, high permeability, and soil sensitivity to large erosion (Nandini, 2012).

The steepness of slope of land in the Batur caldera region varies from flat to $60 \%$. Distribution of prone areas of landslide in Bangli regency is located in areas that have a slope of land above $40 \%$ of which is spread throughout the walls of Batur caldera, both the in and outer caldera and in some spots spread in other Kintamani areas (RTRW, 2013).

The recognition of Batur caldera as the first geopark in Indonesia (year 2012) further 
adds to the commercial value of Kintamani. This attracts entrepreneurs to take advantage of tourist arrivals by providing tourism facilities such as restaurants, guest houses, hot tubs, agro tourism and other tourism facilities (Astawa, 2012). Using Landsat imagery and GIS process, Naningsi (2016) show the land use changes from 1997 to 2014 in Bangli regency that the tourism support facilities development occurred very quickly followed by an increase in residential areas, especially in the district of Kintamani. From the analysis that has been done shows the land use changes in the year 1997-2014 that the plantation increased 19,486.33 ha (36.89\%) and residential increased 1,872.00 ha (3.47\%).

Remote sensing data, especially from satellite remote sensing systems, is very effective in identifying land cover for several reasons (Aggarwal, 2004). This provides a synoptic and comprehensive view for a large area, which is not possible through land surveying (Richards, 2013). The geographic information system (GIS) can also provide a spatial overview of detailed land use and closure (Wirosoedarmo et al., 2014). A GIS technology was developed from 1967 by Roger Tomlinson used for scientific investigation, resource management, development planning, and cartography, and even more profitable than direct field surveys.
GIS can be utilized to help incorporate or overlay between different maps and influence the formation of ground mapping units (Hidayati and Toyibullah, 2011).

The development should be attention to environmental sustainability. The tendency to prioritize the development of the tourism sector in various other places has proven to be the cause of the environment that is not balanced, the beauty and aesthetics of the environment threatened, and unsustainable development (Adnyana et al., 2017). The existence of limited land, it is necessary to evaluation of land use based on land capability class. The objective of this research is to evaluate land use with land capability classification.

\section{METHODOLOGY}

\subsection{Research Location}

The research location is in Batur UNESCO Global Geopark, Kintamani Distric, Bangli Regency, Bali Province. Geographically located in $08^{\circ} 9^{\prime} 48^{\prime \prime} \mathrm{S}$ $08^{\circ} 21^{\prime} 26^{\prime \prime}$ S and $115^{\circ} 17^{\prime} 52^{\prime \prime}$ E- $115^{\circ} 27^{\prime} 28^{\prime \prime}$ E. The total area of Batur UNESCO Global Geopark is $19,422.39$ ha or 37.29 percent of Bangli Regency (Figure 1).

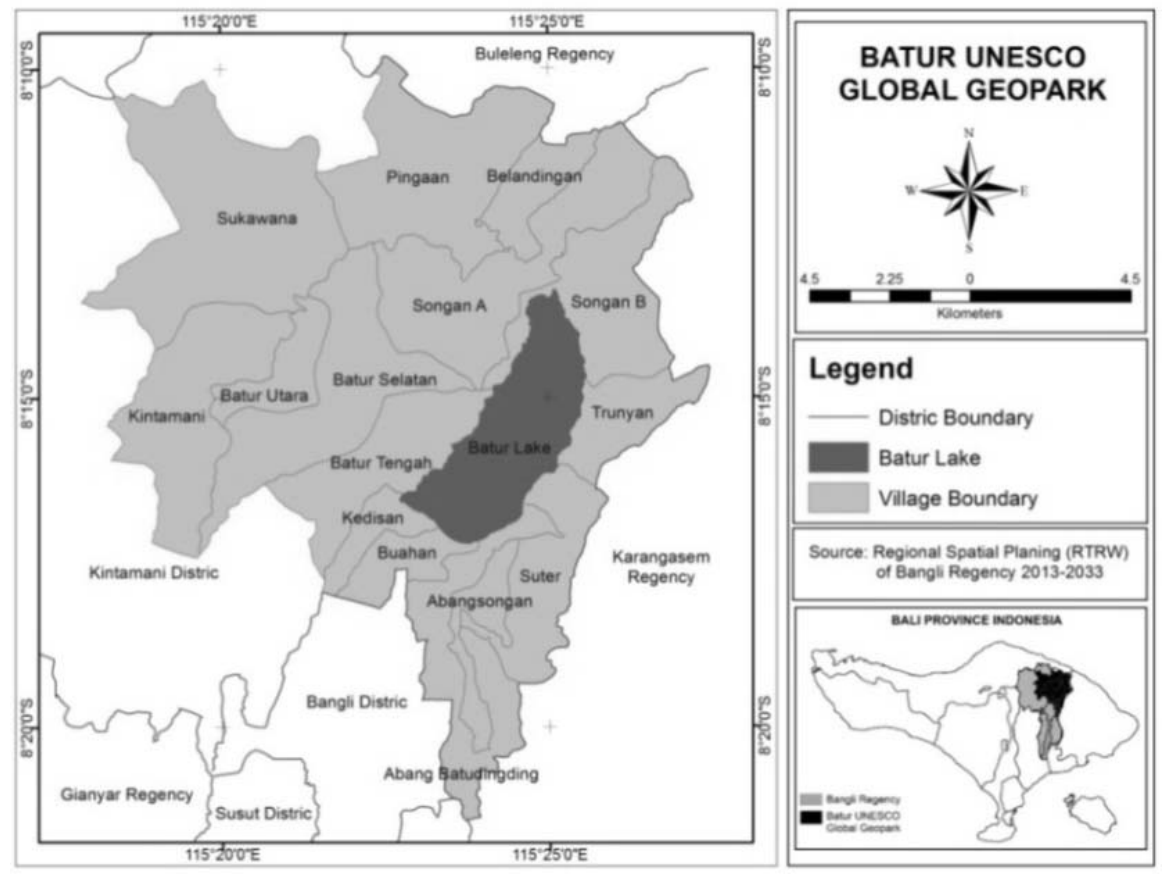

Figure 1.

Research Location 


\subsection{Materials and Method}

The materials of this research are satellite data Landsat $830 \times 30 \mathrm{~m}$ and $15 \times 15$ m Pan-resolution, date 27 September 2017 Path/Row=116/66 download from the website www.earthexplorer.usgs.gov; Worldview 2 and Pleiades imagery of Bangli Regency year record 2013 until 20150.5 x 0.5 m spatial resolution, from Geospatial Information Agency (BIG) Bogor; Advanced Spaceborne Thermal Emission And Reflection Radiometer (ASTER) Global Digital Elevation Model (GDEM) Version 2 of Bali data, resolution $30 \times 30 \mathrm{~m}$, date 16 March
2011 file id (ASTGTM2_S09E115_dem.tif) download from the website www.earthexplorer.usgs.gov.; soil data map scale 1: 50.000 (shp file,) year 2016 from Research Center of Ministry of Agriculture (BBSDLP) Bogor Indonesia; erosion map and flood/puddle map scale 1:50.000 (shp file), year 2017 from Bali-Penida River Region Office (BWS Bali-Penida) Renon Bali.

To conduct land use evaluation of land use with land capability class are processed with GIS according to mechanism as shown in Figure 2.

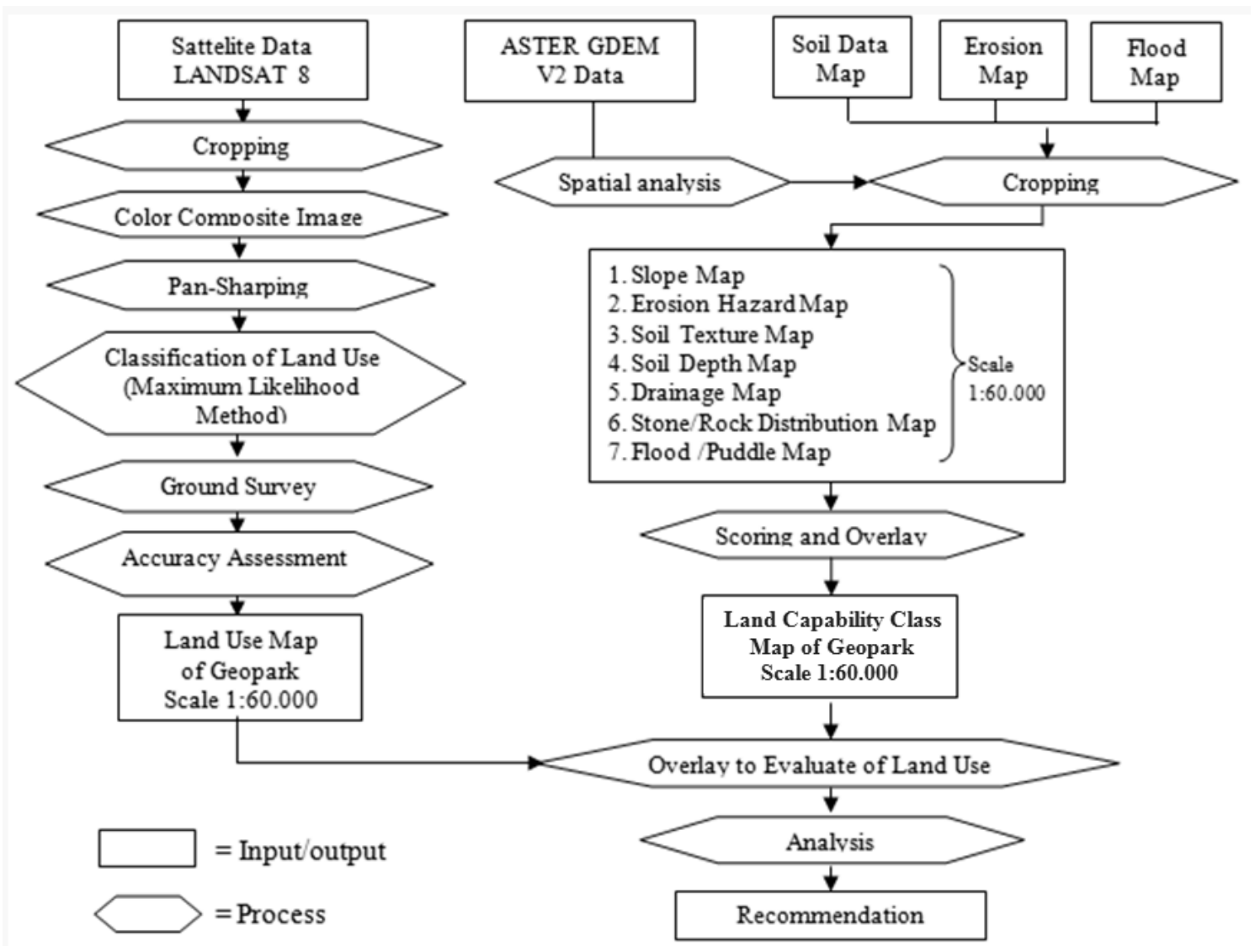

Figure 2.

Data Analysis Mechanism

A. Land Use Map

Data analysis was carried out to determine the land use map, start from preprocessing of satellite data (cropping, color composite image RGB, Pan-sharpening). False color RGB composite with band 6, band 5 and band 2 was used in this research. Refer to Jaya (2010), the Pan-sharpening technique can be used to merges high-resolution panchromatic data with medium-resolution multispectral data to create a multispectral image with high resolution features. The Brovey transformation is based on spectral modeling and was developed to increase the visual contrast in the high and low ends of the 
data's histogram (ESRI, 2005). A maximum likelihood classification algorithm is one of the well known parametric classifies used for supervised classification. According to ERDAS, (1999), the weighted distance or likelihood (D) of unknown measurement vector $\mathrm{X}$ belong to one of the known classes (Mc) is computed based on the Bayesian equation (Eq. 1):

$\mathrm{D}=\ln \left(\mathrm{a}_{\mathrm{c}}\right)-\left[0.5 \ln \left(\left|\mathrm{Cov}_{\mathrm{c}}\right|\right)\right]-\left[0.5\left(\mathrm{X}-\mathrm{M}_{\mathrm{c}}\right) \mathrm{T}\right.$ $\left.\left(\mathrm{Cov}_{\mathrm{c}}-1\right)\left(\mathrm{X}-\mathrm{M}_{\mathrm{c}}\right)\right]$

where:

$\begin{array}{ll}\mathrm{D} & =\text { weighteddistance (likelihood) } \\ \mathrm{C} & =\text { a particular class } \\ \mathrm{X} & =\text { unclassified vector based } \\ \mathrm{Mc} & =\text { predetermined class } \\ \mathrm{a}_{\mathrm{c}} & =\text { percent probability that any }\end{array}$ candidate pixel is a member of class c (defaults to 1.0, or is entered from a priori knowledge)

$\operatorname{Cov}_{\mathrm{c}}=$ the covariance matrix of the pixels in the sample of class c

$\left|\operatorname{Cov}_{c}\right|=$ determinant of $\operatorname{Cov}_{c}$ (matrix algebra)

$\mathrm{Cov}_{\mathrm{c}}-1$ = inverse of Covc (matrix algebra)

$\mathrm{T}=$ transposition function (matrix algebra)

Ground check were conducted by random sampling method proportionally of area of each class with 86 points coordinate using Geographic Positioning System (GPS). Accuracy analysis was conducted to determine the accuracy of the classification made. The equations used to measure the estimated overall accuracy, user's accuracy, producer's accuracy and kappa coefficient are as equation 2 - equation 5 .

Overall Accuracy $=\frac{\sum_{i=1}^{r} X i i}{N} \times 100 \%$

User's Accuracy $=\left(X i i / X_{i^{+}}\right) \times 100 \%$

Producer's Accuracy $=\left(X i i / X_{+i}\right) \times 100 \%$

$\operatorname{Kappa}(K)=\frac{n \sum_{i-1}^{r} X i i-\sum_{i-1}^{r}(X i+* X+i)}{n 2-\sum_{i-1}^{r}(X i+* X+i)} \times 100 \%$

where:

$r \quad=$ number of row and column in cross

classification table,

$n \quad=$ number of pixels in the example,
Xii $=$ number of combinations along the diagonal,

$X_{i^{+}} \quad=$ observations in row $\mathrm{i}$, and

$X_{+i} \quad=$ observations in column i.

\section{B. Land Capability Classification}

Base on the method of "differentiator pixel value" (Adnyana and As-syakur, 2012) developed from improvisation overlay methods, reclassification of differentiator classes into the differentiator value of a raster data pixel representing each class of land capability and its limiting factor (Arsyad, 2012). These pixel values are incorporated into a limiting factor map, then overlaid and generated new differentiator pixel values in the land capability map along with its limiting factors using the formula 6. The differentiating values for each limiting factors are shows as Table 1 - Table 7 . After the sum, the highest value of the numbered series will show the class as well as the soil limiting factors. This analyzes process uses GIS software.

$$
\mathrm{LC}=\mathrm{VR}+\mathrm{VE}+\mathrm{VT}+\mathrm{VK}+\mathrm{VD}+\mathrm{VL}
$$

$+\mathrm{VB}$

where:

LC = Land capability class

VR = Value of slope

$\mathrm{VE} \quad=$ Value of erosion

$\mathrm{VT} \quad=$ Value of texture

VK = Value of effective depth

$\mathrm{VD}=$ Value of drainage

$\mathrm{VL} \quad=$ Value of stone/rock

VB = Value of flood/puddle

The sum values then obtained a series of numbers each representing the limiting factor, detail shown in following illustration:

\begin{tabular}{|l|l|l|l|l|l|l|}
\hline a & b & c & d & e & f & g \\
\hline
\end{tabular}

where:

$\mathrm{a}=$ Limiting factor of slope

$\mathrm{b}=$ Limiting factor of erosion

$\mathrm{c}=$ Limiting factor of texture

$\mathrm{d}=$ Limiting factor of effective depth

$\mathrm{e}=$ Limiting factor of drainage

$\mathrm{f}=$ Limiting factor of stone/rock

$\mathrm{g}=$ Limiting factor of flood/puddle 
As for the land capability class is known from the highest value among the series of the numbers. For example if value LC $=1133112$ then class of land capability is
III with limiting factor soil texture and soil effective depth. Below is shown table of differentiator values of classes of land capability and limiting factors.
Table 1.Value of Slope Factor (l)

\begin{tabular}{cccc}
\hline Code & Slope & Class & Value \\
\hline$l_{0}$ & $0-3 \%$ & I & 1000000 \\
\hline$l_{1}$ & $3-8 \%$ & II & 2000000 \\
\hline$l_{2}$ & $8-15 \%$ & III & 3000000 \\
\hline$l_{3}$ & $15-25 \%$ & IV & 4000000 \\
\hline$l_{4}$ & $25-45 \%$ & VI & 6000000 \\
\hline$l_{5}$ & $45-65 \%$ & VII & 7000000 \\
\hline$l_{6}$ & $>65 \%$ & VIII & 8000000
\end{tabular}

Table 3.Value of Soil Texture Factor (t)

\begin{tabular}{|c|c|c|c|}
\hline Code & Texture & Class & Value \\
\hline $\mathrm{t}_{1}$ & Loam, Silt loam & II & 20000 \\
\hline $\mathrm{t}_{2}$ & $\begin{array}{l}\text { Sandy loam, } \\
\text { Silty clay loam, } \\
\text { Clay loam, } \\
\text { Sandy clay loam }\end{array}$ & $\mathrm{I}$ & 10000 \\
\hline $\mathrm{t}_{3}$ & $\begin{array}{l}\text { Silt, Silty clay, } \\
\text { Clay }\end{array}$ & III & 30000 \\
\hline $\mathrm{t}_{4}$ & Sandy clay & IV & 40000 \\
\hline$t_{5}$ & $\begin{array}{l}\text { Loamy sand, } \\
\text { Sand }\end{array}$ & VIII & 80000 \\
\hline
\end{tabular}

Table 5. Value of Soil Drainage Factor (d)

\begin{tabular}{clcc}
\hline Code & Drainage & Class & Value \\
\hline $\mathrm{d}_{0}$ & Good & I & 100 \\
\hline $\mathrm{d}_{1}$ & $\begin{array}{l}\text { Rather } \\
\text { good }\end{array}$ & I & 100 \\
\hline $\mathrm{d}_{2}$ & Rather bad & II & 200 \\
\hline $\mathrm{d}_{3}$ & Bad & III & 300 \\
\hline $\mathrm{d}_{4}$ & Very bad & IV & 400
\end{tabular}

Table 2.Value of Erosion Factor (e)

\begin{tabular}{clcc}
\hline Code & \multicolumn{1}{c}{ Erosion } & Class & Value \\
\hline $\mathrm{e}_{0}$ & Not erosion & I & 100000 \\
& & & \\
\hline $\mathrm{e}_{1}$ & Low & II & 200000 \\
\hline $\mathrm{e}_{2}$ & Medium & IV & 400000 \\
\hline $\mathrm{e}_{3}$ & High & VI & 600000 \\
\hline $\mathrm{e}_{4}$ & Very high & VII & 700000 \\
\hline
\end{tabular}

Table 4. Value of Soil Effective Depth Factor(k)

\begin{tabular}{clcc}
\hline Code & \multicolumn{1}{c}{ Effective Depth } & Class & Value \\
\hline $\mathrm{k}_{0}$ & Deep $(>90 \mathrm{~cm})$ & I & 1000 \\
\hline $\mathrm{k}_{1}$ & $\begin{array}{l}\text { Moderately deep }(90- \\
50 \mathrm{~cm})\end{array}$ & III & 3000 \\
\hline $\mathrm{k}_{2}$ & Shallow $(50-25 \mathrm{~cm})$ & IV & 4000 \\
\hline $\mathrm{k}_{3}$ & Very shallow $(<25 \mathrm{~cm})$ & VI & 6000 \\
\hline
\end{tabular}

Table 6. Value of Stone/Rock Factor (b)

\begin{tabular}{|c|c|c|c|}
\hline Code & Litology & Class & Value \\
\hline \multirow{3}{*}{$\mathrm{b}_{0}$} & SR(0-<15\%) & & \\
\hline & $\mathrm{S}(0-<0.01 \%)$ & I & 10 \\
\hline & $\mathrm{R}(0-<2 \%)$ & & \\
\hline \multirow{3}{*}{$\mathrm{b}_{1}$} & SR $(15-<50 \%)$ & & \\
\hline & S $(0.01-<3 \%)$ & IV & 40 \\
\hline & $\mathrm{R}(2-<10 \%)$ & & \\
\hline \multirow{3}{*}{$\mathrm{b}_{2}$} & SR (50-<90\%) & & \\
\hline & S (3-<15\%) & V & 50 \\
\hline & $\mathrm{R}(10-<50 \%)$ & & \\
\hline \multirow{3}{*}{ b3 } & $\mathrm{SR}(>90 \%)$ & & \\
\hline & S (15-90\%) & VIII & 80 \\
\hline & R (50-90\%) & & \\
\hline
\end{tabular}


Table 7. Value of Flood/Puddle Factor (o)

\begin{tabular}{clcc}
\hline Code & \multicolumn{1}{c}{ Flood / puddle } & Class & Value \\
\hline 00 & $\begin{array}{l}\text { Never: in a one year period of land never covered the } \\
\text { flood for more time than24 hours } \\
\text { 01 }\end{array}$ & $\begin{array}{l}\text { Sometimes: floods that cover more ground from 24 hours } \\
\text { of irregular occurrence in period less than a month. }\end{array}$ & II \\
02 & $\begin{array}{l}\text { For a period of one month in a year regularly covered by } \\
\text { floods for a period of time more than 24 hours. }\end{array}$ & IV & 4 \\
03 & $\begin{array}{l}\text { For 2-5 months of the year, on a monthly basis regularly } \\
\text { always overwhelmed by more than 24 floods hour } \\
\text { For six months or more land always flooded regularly } \\
\text { over time from 24 hours }\end{array}$ & VI & 6 \\
\hline
\end{tabular}

C. Evaluation of Land Use

Evaluation of land use suitability is conducted by comparing land use with land capability class. In this process, there is an overlay between the land use map and the land capability class map. The result will be shown in map and table.

\section{RESULT AND DISCUSION}

\section{A. Land Use Map}

Using GIS analysis, it is obtained the area and percentage of each classes land use in the research area such as Figure 3 and Table 8.

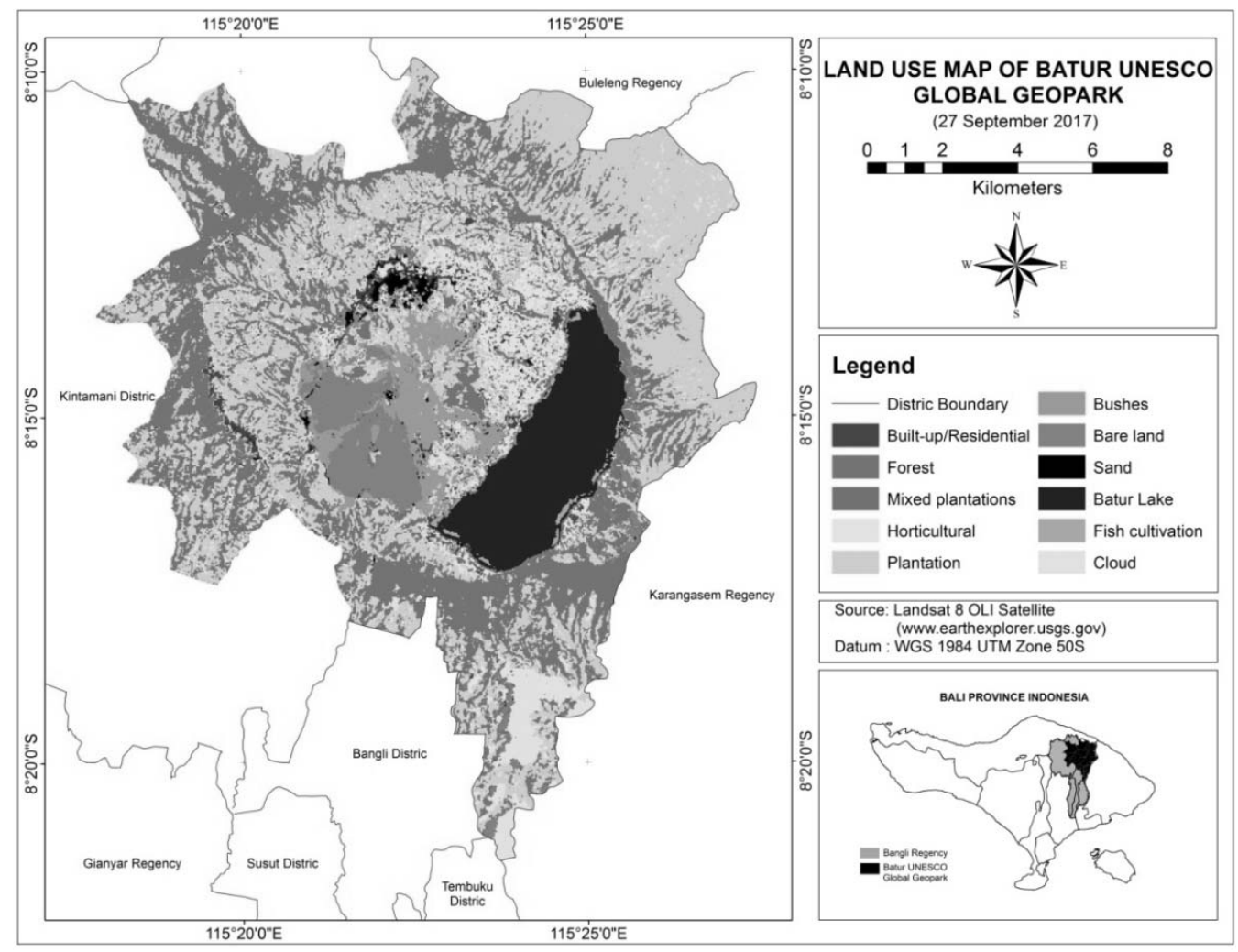

Figure 3.

Land Use Map of Batur UNESCO Global Geopark 
Table 8. Area and Percentage Based on Classification Results

\begin{tabular}{clcc}
\hline No & Classes of land use & Area (ha) & Percentage \\
\hline 1 & Built-up/Residential & 430.36 & $2.22 \%$ \\
2 & Forest & $3,901.22$ & $20.09 \%$ \\
3 & Mixed plantations & $2,107.22$ & $10.85 \%$ \\
4 & Horticultural & $1,736.43$ & $8.94 \%$ \\
5 & Plantation & $7,317.60$ & $37.68 \%$ \\
6 & Bushes & 933.12 & $4.80 \%$ \\
7 & Bare land & $1,003.63$ & $5.17 \%$ \\
8 & Sand & 112.84 & $0.58 \%$ \\
9 & Batur Lake & $1,532.09$ & $7.89 \%$ \\
10 & Fish cultivation & 64.21 & $0.33 \%$ \\
11 & Cloud & 283.67 & $1.46 \%$ \\
\hline \multicolumn{2}{r}{ Total } & $\mathbf{1 9 , 4 2 2 . 3 9}$ & $\mathbf{1 0 0 . 0 0}$ \\
\hline
\end{tabular}

The overall accuracy based on equation number 2 obtain value 86,05\% and Kappa accuracy based on the equation of number 5 obtained value 0.83 . Calculation of the overall accuracy shows that the process of map classification is acceptable because it has an overall accuracy value of more than $85 \%$ (Anderson, 1976). Meanwhile, according to Landis and Koch (1977), the coefficient value of kappa $0.81-1$ is included in very high category, this means that the value of the accuracy test on the classification results can be trusted.

B. Land Capability Classification

Results of image processing ASTER GDEM V2 uses GIS software through the

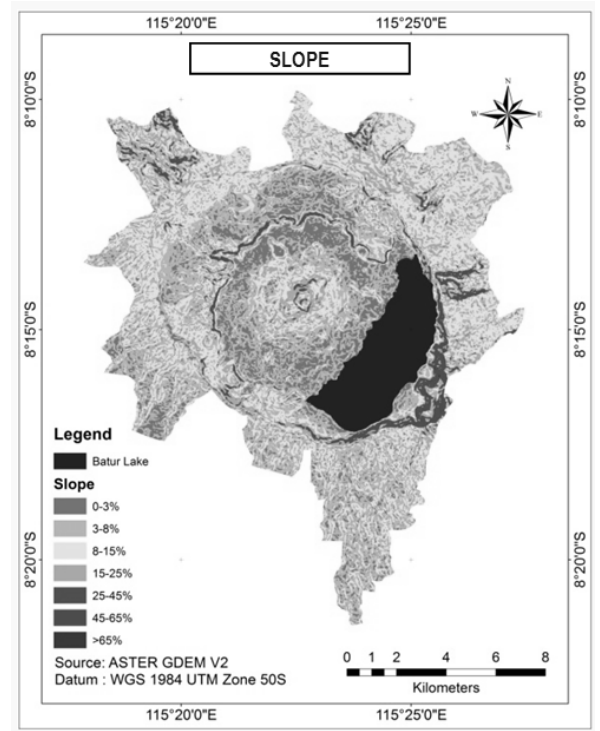

Figure 4.

Slope Map cropping process and spatial analysis based on Table 1 obtained result as shown in Figure 4. In classification capability, the slope is divided into seven criteria. Furthermore, erosion and flood maps obtained from BWS Bali Penida after crop in accordance with research area are shown in Figure 5 and Figure 10.

The soil type and morphological maps containing the mapping information of Agriculture Ministry, further cropped and processed using GIS software obtained soil texture map (Figure 6), effective depth map (Figure 7), soil drainage map (Figure 8), and stone/rock distribution map (Figure 9).

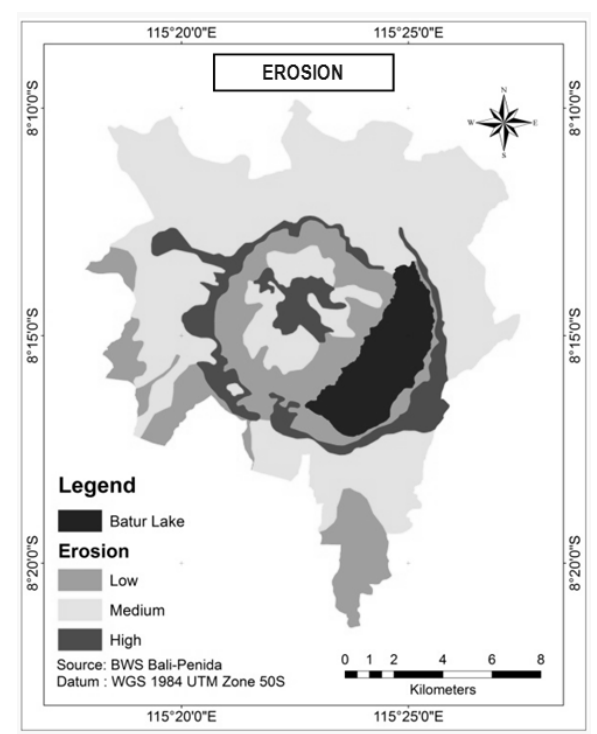

Figure 5.

Erosion Map 


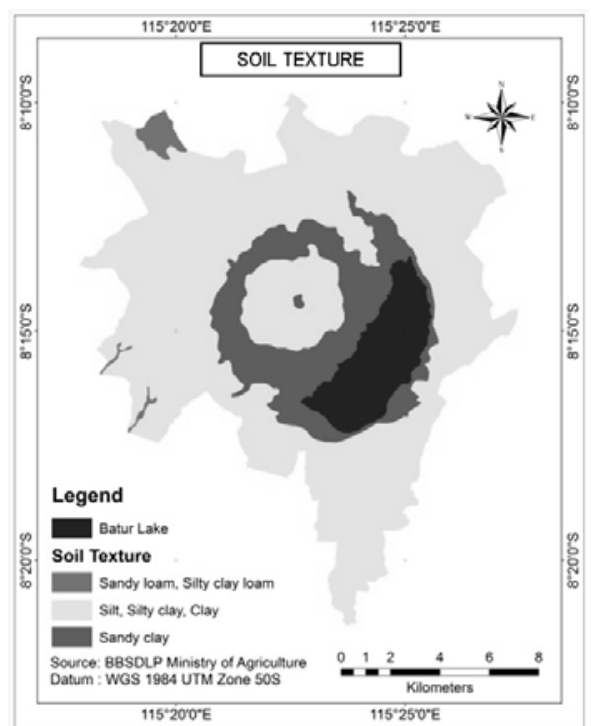

Figure 6.

Soil Texture Map

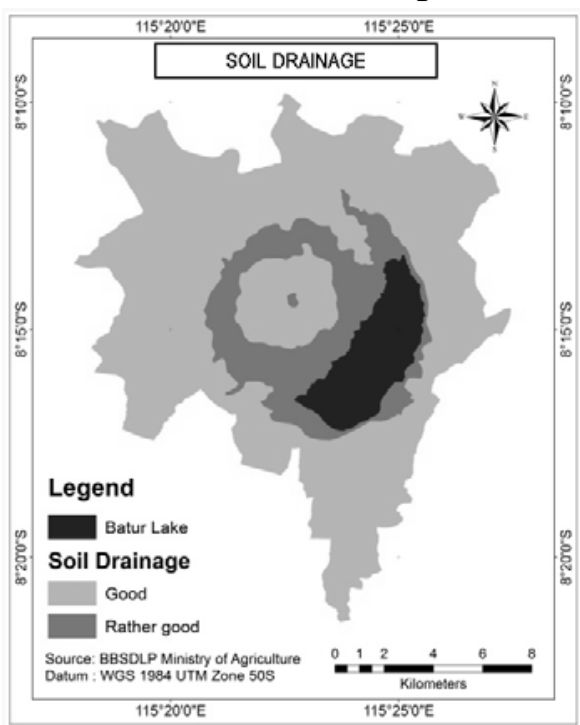

Figure 8.

Soil Drainage Map

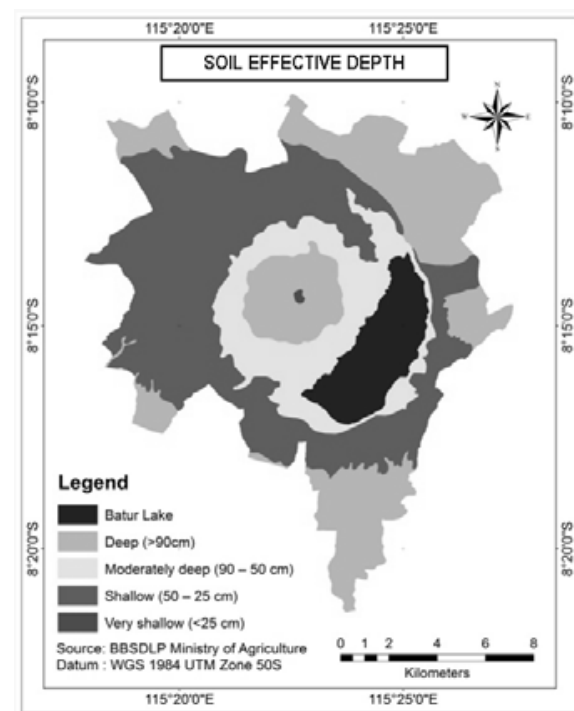

Figure 7.

Soil Effective Depth Map

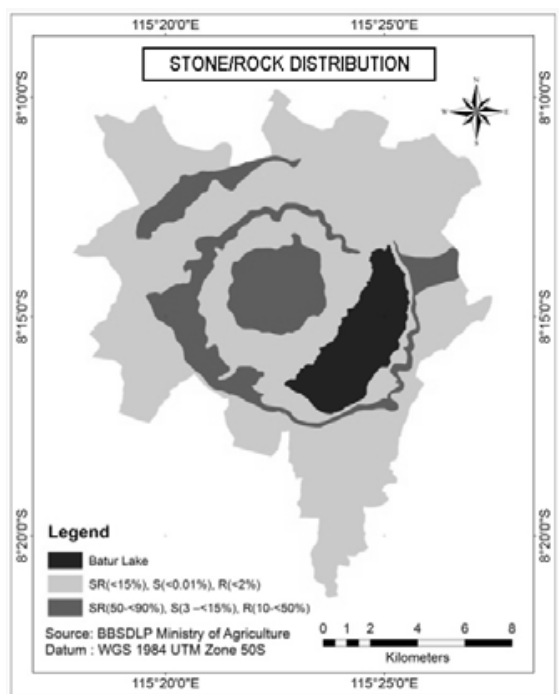

Figure 9.

Stone/Rock Distribution Map

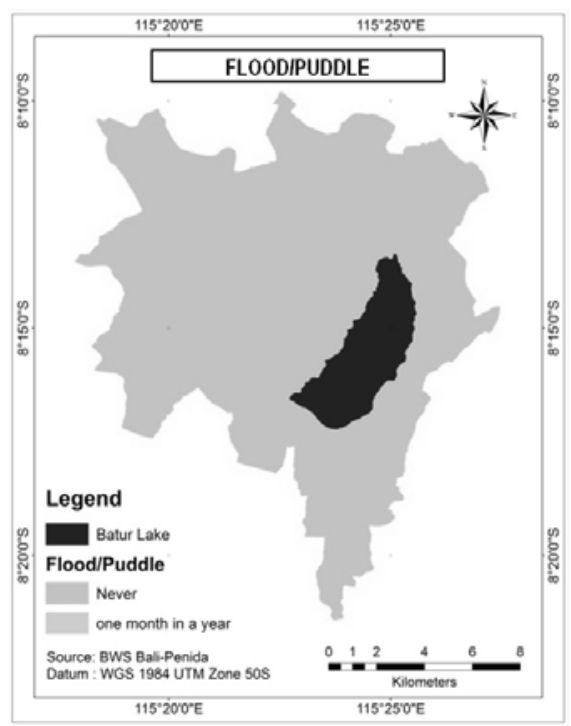

Figure 10.

Flood/Puddle Map 
The land capability class map is derived from overlays based on the method of "differentiator pixel value" (Adnyana and Assyakur, 2012). Calculation of the different pixel value in the attribute table in overlays process has resulted in a series of numbers describing the land capability class and its limiting factors. The highest value of the numerical sequence describes the capability class of land contained in the pixel, whereas the position of the highest number of rows (in the form of unit, tens, hundreds, and so on) indicates the type of limiting factor of the land capability class. Using GIS analysis, it is known that the land capability classification of Batur UNESCO Global Geopark area (Figure 11).

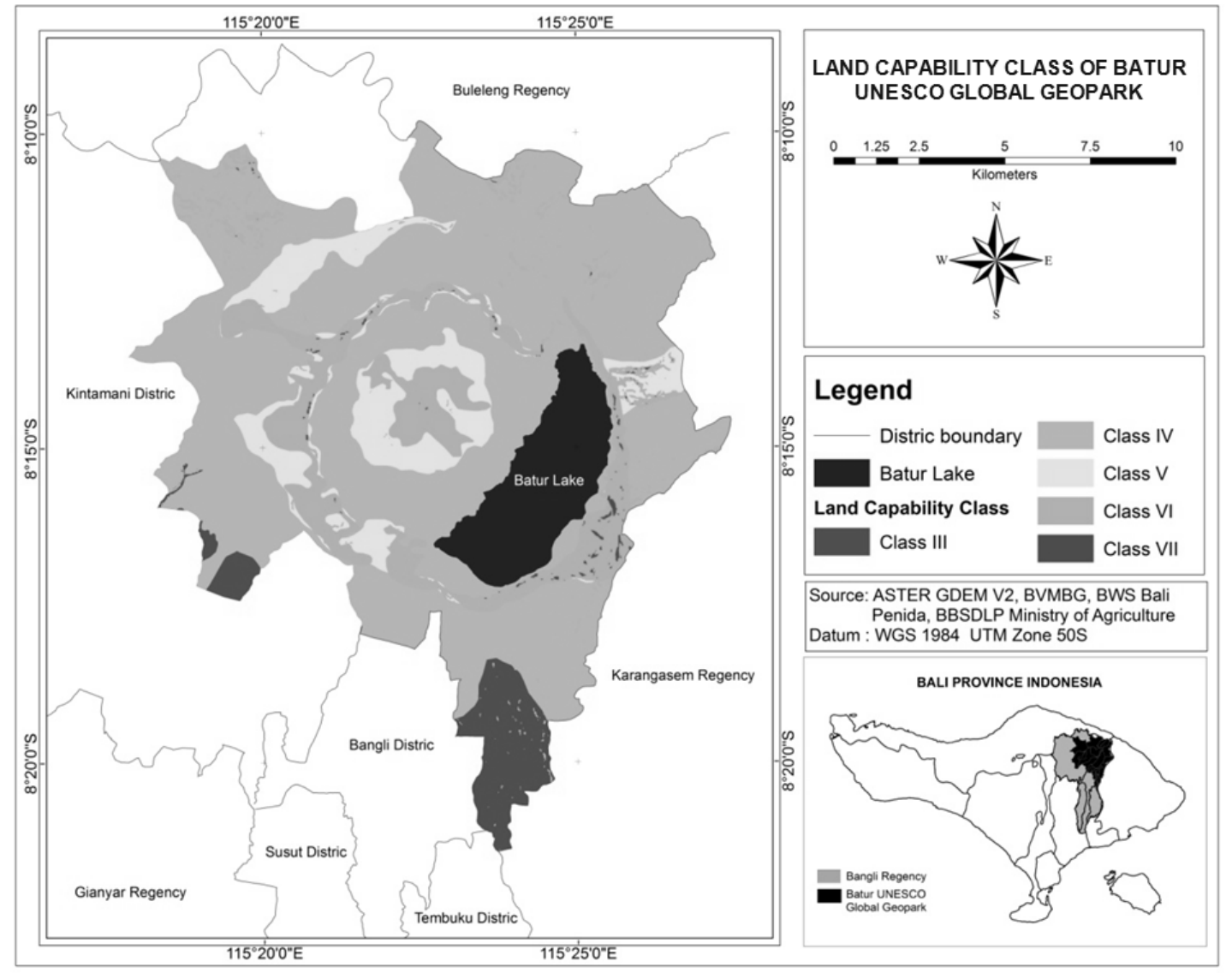

Figure 11.

Land Capability Class Map

Table 9. Area and Percentage of Each Class

\begin{tabular}{ccrc}
\hline No. & Class & Area (ha) & Percentage (\%) \\
\hline 1. & III & $1,046.24$ & 5.87 \\
2. & IV & $12,243.73$ & 68.72 \\
3. & V & $1,922.14$ & 10.79 \\
4. & VI & $2,550.16$ & 14.31 \\
5. & VII & 53.66 & 0.30 \\
\hline & Total & $\mathbf{1 7 , 8 1 5 . 9 3}$ & $\mathbf{1 0 0 . 0 0}$ \\
\hline
\end{tabular}

The each area of land capability class is then shown in Table 9. The total area obtained in the table is not included with a Batur Lake (1,606.46 ha). 
Table 9 show, the land class III with slope $8-15 \%$ and medium soil texture limiting factor are located in Abang Songan, Abang Batudinding, Suter, Batur Selatan and Kintamani village area of 1,046.24 ha (5.87\%). Land class IV with slope $15-25 \%$, medium erosion, sandy clay soil texture, shallow soil depth and regularly covered by floods/puddle one month per year limiting factor spread in all village area of $12,243.73$ ha (68.72\%). Land class $\mathrm{V}$ with distribution small rocks ( $50-<90 \%)$, stone $(3-<15 \%)$, rock $(10-<50 \%)$ limiting factor area of 1,922.14 ha (10.79\%) spread in Batur Utara, Batur Tengah, Batur Selatan, Kintamani, Sukawana, Pinggan, Songan A, and Songan B. Land class VI with slope $25-45 \%$, high erosion, and very shallow $(<25 \mathrm{~cm})$ effective depth limiting factor area of 2,550.16 ha (14.31\%) are scattered in Suter, Trunyan, Songan A, Songan B, Abang Batudinding, Sukawana and Pinggan village. Land class VII with slope $45-65 \%$ limiting factor area of 53.66 ha
$(0.30 \%)$ spread in 10 villages that are Songan A, Songan B, Trunyan, Suter, Abang Batudinding, Buahan, Batur Selatan, Batur Utara, Kintamani, Sukawana, and Pinggan.

Based on Klingebiel and Motgomery (1961) land capability classification is divided into 8 classes. The classification in accordance with the results, in Batur UNESCO Global Geopark area sequentially dominated by class IV (68.70\%) followed by class VI (14.31\%), class V (10.79\%), class III (5.87\%), and class VII (0.30\%).

C. Evaluation land Use with Land Capability Class

Land use maps that have been obtained from classification process then overlay with a map of land capability class. The overlay can be seen each suitability of current land use with the ability of land in the area of Batur UNESCO Global Geopark. In more detail the results of its evaluation are shown in Figure 12 and Table 10.

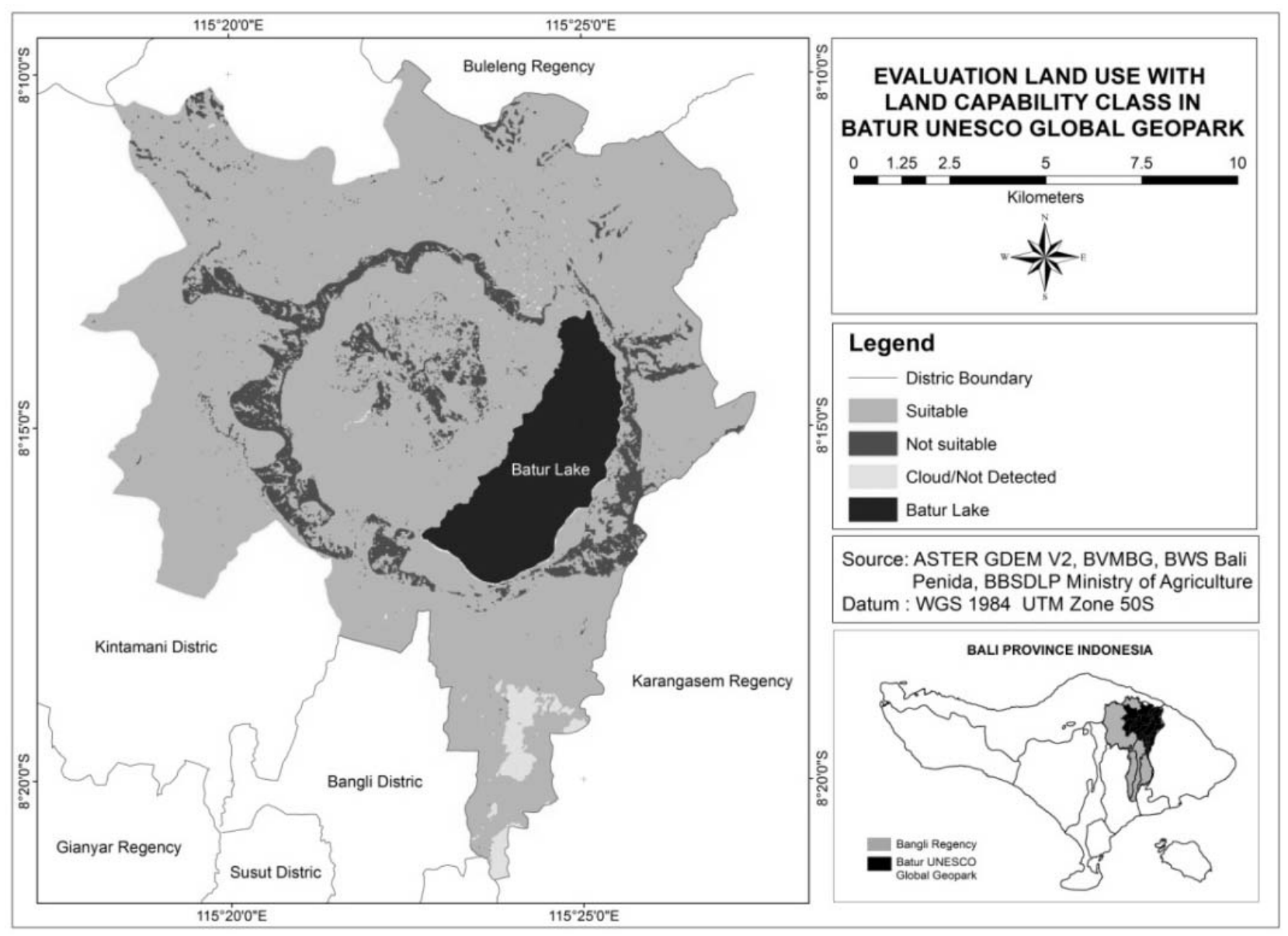

Figure 12.

Map of Evaluation Land Use with Land Capability Class 
Table 10. Evaluation of Land Use with Land Capability Class

\begin{tabular}{|c|c|c|c|c|c|c|}
\hline \multirow{2}{*}{ No. } & \multirow{2}{*}{ Land use } & \multicolumn{5}{|c|}{ Land Capability Class (ha) } \\
\hline & & III & IV & V & VI & VII \\
\hline \multicolumn{7}{|c|}{ 1. Built-up/Residential } \\
\hline & Slope $<8 \%$ & 5.48 & 334.02 & 28.62 & - & - \\
\hline & Slope $>8 \%$ & 1.51 & 25.10 & 10.99 & 23.97 & 0.67 \\
\hline & Forest & 123.60 & $2,736.89$ & 319.98 & 714.54 & 6.21 \\
\hline & Mixed plantations & 111.04 & $1,415.20$ & 235.72 & 340.50 & 4.76 \\
\hline 4. & Horticultural & 143.29 & $1,352.60$ & 123.33 & 115.64 & 1.57 \\
\hline 5. & Plantation & 399.32 & $5,187.58$ & 759.40 & 952.45 & 18.85 \\
\hline & Bushes & 0.45 & 413.56 & 243.91 & 274.49 & 0.71 \\
\hline 7. & Bare land & 52.74 & 603.19 & 195.11 & 121.54 & 20.89 \\
\hline 8. & Sand & 0.56 & 104.79 & 2.49 & 5.00 & - \\
\hline \multicolumn{2}{|r|}{ Total } & 837.99 & $12,172.93$ & $1,919.55$ & $2,548.13$ & 53.66 \\
\hline
\end{tabular}

Land capability class III have more restrictions than those in class II and when used for cultivated crops the conservation practices are usually more difficult to apply and to maintain (Arsyad, 2012). They may be used for cultivated crops, pasture, woodland, range, or wildlife food and cover. In this class was found the suitability of land use for plantation 399.32 ha $(2.24 \%)$, horticultural 143.29 ha $(0.80 \%)$, forest 123.60 ha $(0.69 \%)$, mixed plantations 111.04 ha $(0.62 \%)$, bare land 52.74 ha $(0.30 \%)$, built up 5.48 ha $(0.03 \%)$, sand 0.56 and bushes 0.45 ha. In this class also was found not suitability land use for built-up/residential 1.51 ha because limiting factor of slope and erosion.

Land capability class IV is naturally suitable for agriculture including annual or horticultural but for the use of horticultural requires more careful management and conservation measures such as terracing and regular fertilization. The land use in this class is mostly used for plantation that is $5,187.58$ ha $(29.12 \%)$ and $1,352.60$ ha $(7.59 \%)$ for horticultural. In this class founds builtup/residential 359.12 ha (2.02\%). Referring to Indonesia Minister of Environment Regulation Number 17, 2009 in this class not suitable for built-up/residential, but if calculate from the land slope (slope $<8 \%$ ) and erosion limiting factor, suitable land use for built-up/residential in this class 334.02 ha (1.87\%).

Land capability class V naturally has barriers that limit the choice of plants, and inhibits soil cultivation for seasonal crops making it more suitable for mixed plantation or plantation. The land use for plantation and mixed plantations each area of 759.40 ha (4.26\%) and 235.72 ha (1.32\%). In this class was found not suitable land use for horticultural 123.33 ha $(0.69 \%)$ with various types of horticultural such as onions, tomatoes, chili, etc. In class $\mathrm{V}$ found builtup/residential suitable area of 28.62 ha $(0.16 \%)$ and not suitable 10.99 ha $(0.06 \%)$.

Land capability class VI has severe constraints that make this soil not suitable for agricultural use, making it more suitable for shrubs. In this class was found not suitable land use for plantation 952.45 ha (5.35\%), mixed plantation 340.50 ha $(1.91 \%)$ and horticultural 115.64 ha $(0.65 \%)$, builtup/residential 23.97 ha $(0.13 \%)$, and sand 5 ha $(0.03 \%)$.

Land capability class VII land is not suitable for agricultural cultivation, if used for grasslands or production forests should be carried out with severe erosion prevention efforts. In fact, the bare land area of 20.89 ha $(0.12 \%)$, another land use is still used for plantation 18.85 ha $(0.11 \%)$, mixed plantation 4.76 ha $(0.03 \%)$, horticultural 1.57 ha, bushes 0.71 ha and built-up/residential 0.67 ha. Overall percentage of suitable area between land use with land capability class in Batur UNESCO Global Geopark is $88.49 \%$ (Table $11)$. 
Table 11. Percentage Suitability Area of Evaluation Land Use with Land Capability Class

\begin{tabular}{cccc}
\hline No. & Suitability & Area (ha) & Percentage (\%) \\
\hline 1. & Suitable & $15,764.78$ & 88.49 \\
2. & Not suitable & $1,767.48$ & 9.92 \\
3. & Clouds/Not detected & 283.67 & 1.59 \\
\hline & Total & $\mathbf{1 7 , 8 1 5 . 9 3}$ & $\mathbf{1 0 0 . 0 0}$ \\
\hline
\end{tabular}

\section{CONCLUTION}

The condition of land capability Batur UNESCO Global Geopark dominated by class IV $12,243.73$ ha $(68.72 \%)$, followed by class VI 2,550.16 ha (14.31\%), class V 1,922.14 ha (10.79\%), class III 1,046.24 ha (5.87\%), and class VII 53.66 ha (0.29\%). Evaluation result of land use with land capability class overall has suitable area $15,764.78$ ha $(88.49 \%)$, not suitable area $1,767.48$ ha $(9.92 \%)$ and not detected/cloud interference 283.67 ha (1.59\%) of $17,815.93$ ha total area. Suggestions for research development and all stakeholders in Batur UNESCO Global Geopark area are: 1) needed further research to use high resolution satellites to obtain higher accuracy, 2) needed public awareness in Batur UNESCO Global Geopark area always refers to land capability class, and 3) local government need to supervise and guide to ensure land use in the UNESCO Batur Global Geopark area always refers to the land capability class.

\section{REFERENCES}

Adnyana, I M., Puja, I N., and Arthagama, I D.M. 2017. Evaluasi dan Penetapan Lahan Pertanian Berkelanjutan untuk Pencegahan Alih Fungsi Lahan di Kabupaten Bangli. Ecotrophic 11 No. 1: 76 - 80. Available from: https://ojs.unud.ac.id/index.php/ECOTR OPHIC/article/view/31644.

Adnyana, I W.S., and As-syakur, A.R. 2012. Application of Geographic Information System (GIS) Based Raster Data to Classify Land Capability in Bali Province by using differentiator pixel value method. Manusia dan Lingkungan Journal 19 No. 1: 21-29.
Aggarwal, S. 2004. Principles of Remote Sensing. In: Sivakumar, M.V.K., Roy, P.S., Harmsen, K., Saha,S.K., editors. Satellite Remote Sensing and GIS Applications in Agricultural Meteorology. Geneva: World Meteorological Organisation. p. 23-38.

Agustini, N.L.P.K. 2015. "Destination Management and Imaging Kintamani Towards Sustainable Tourism” (Dissertation) Denpasar: Udayana University. Available from: http://erepo.unud.ac.id/10100/1/4f6bbe3 5ad8d7260e6cb25964432a49a.pdf.

Anderson, J.R., Hardy, E.E., Roach, J.T., and Witmer, R.E., 1976 Land Use and Land Cover Classification System for Use with Remote Sensor Data. Washington: Geological Survey Professional Paper $964 . \quad$ Available from:https://pubs.usgs.gov/pp/0964/rep ort.pdf.

Arsyad, S. 2012. Konservasi Tanah dan Air Edisi Kedua. Bogor: IPB Press.

Astawa, I.B.M. 2012. Potensi Sumber daya Alam dan Pengelolaannya untuk Mendukung Kehidupan Sosial Masyarakat Adat Kawasan Gunung Batur Bangli. Socia, 11: 43-57.

RTRW. 2013. Peraturan Daerah Kabupaten Bangli Nomor 9 Tahun 2013 tentang Rencana Tata Ruang Wilayah Kabupaten Bangli. Bangli: Government of Bangli Regency.

BBSDLP, 2016. Soil Type Map of Bangli Regency. Bogor: Ministry of Agriculture. 
ERDAS. 1999. Field Guide Fifth Edition, Revised and Expanded .US: ERDAS Worldwide Headquarters. Available from:

http://web.pdx.edu/ emch/ip1/FieldGui de.pdf.

ESRI. 2005. GIS Solutions for Environmental Management. New York: Environmental Systems Research Institute, Inc. Available from: http://www.esri.com/library/brochures/p dfs/gis-sols-for-env-mgmt.pdf.

Hidayati, I. N., and Toyibullah Y. 2011. Kajian Indeks Potensi Lahan Terhadap Pemanfaatan Rencana Tata Ruang Wilayah Menggunakan Sistem Informasi Geografis di Kabupaten Sragen. Globë, 13 (No. 2): 156-164.

Jaya, I N.S. 2010. Analisis Citra Digital Perspektif Penginderaan Jauh untuk Pengelolaan Sumber Daya Alam. Bogor: IPB Press.

Klingebiel, A.A., and Montgomery, P.H. 1961. Land-Capability Classification. Agriculture Handbook No. 210. Washington D.C.: Soil Conservation Service U.S. Department Of Agriculture. Available from: https://www.nrcs.usda.gov/Internet/FSE _DOCUMENTS/nrcs142p2_052290.pd f.

Knight, E.J., and Kvaran, G. 2014. Landsat-8 Operational Land Imager Design, Characterization, and Performance. Remote Sensing. 6: 10286-10305.

Landis, J., and Koch, G. 1977. The Measurement of Observer Agreement for Categorical Data. Biometrics 33:159-74 available from https://www.dentalage.co.uk/wpcontent/uploads/2014/09/landis_jr__k och_gg_1977_kappa_and_observer_a greement.pdf.

Nampa, W. 2011. "Pemanfaatan Sistem Informasi Geografis (SIG) Dalam Penataan Kawasan Agroindustri Kopi Arabika di Kecamatan Kintamani Kabupaten Bangli” (tesis). Denpasar:Udayana University.
Nandini, R., and Narendra, B. H. 2012. Critical Land Characteristics of Former Eruption of Batur Mount in Bangli District, Bali. Jurnal Penelitian Hutan dan Konservasi Alam Vol 9 No. 3: 199211. Available from: http://fordamof.org/files/01_Ryke_OK.pdf.

Naningsi, N. 2016. "Study of Land Use Change From 1997 to 2014 Using Landsat Data In Bangli Regency" (tesis). Denpasar:Udayana University.

Richards, J.A. 2013. Remote Sensing Digital Image Analysis: An Introduction. 5th. New York: Springer Heidelberg.

Stehman, S. 1997. Estimating Standard Errors of Accuracy Assessment Statistics Under Cluster Sampling. Remote Sensing of Environment, 60: 258-269.

USGS. 2016. Landsat 8 (L8) Data Users Handbook version 2.0. USA: Department of the Interior U.S. Geological Survey. Available from: https://landsat.usgs.gov/sites/default/file s/documents/Landsat8DataUsersHandb ook.pdf.

Wirosoedarmo, R., Widiatmono J.B.R., and Widyoseno, Y. 2014. RTRW

Arrangement Based on Environmental Supportability Based on Land Capability. Agritech, 34 (No. 4): 463472. Available from: https://media.neliti.com/media/publicati ons/92932-ID-rencana-tata-ruangwilayah-rtrw-berdasar.pdf. 